\title{
ATTITUDES ABOUT CANNABIS AND CANNABIS USE IN TWO CONSECUTIVE STUDIES AMONG THE GENERAL POPULATION IN CROATIA
}

\author{
Renata Glavak Tkalić \\ Institute of Social Sciences Ivo Pilar \\ Marulićev trg 19/I, 10000 Zagreb \\ renata.glavak.tkalic@pilar.hr \\ Josip Razum \\ Institute of Social Sciences Ivo Pilar \\ Marulićev trg 19/I, 10000 Zagreb \\ josip.razum@pilar.hr \\ Anja Wertag \\ Institute of Social Sciences Ivo Pilar \\ Marulićev trg 19/I, 10000 Zagreb \\ anja.wertag@pilar.hr
}

\begin{abstract}
Cannabis is the most commonly used illicit drug in Croatia. Although some people seem to use cannabis without adverse consequences, widespread cannabis use still poses a significant burden on public health. The aims of this study ware to determine if prevalence of cannabis use and cannabis attitudes changed between the two study waves, and to determine wich groups regarding cannabis user and attitudes exist in the Croatian general population and did they change between the two study waves. The research was conducted on two representative samples of Croatian citizens aged between 15 and 64 years, first collected in $2011(\mathrm{~N}=4756)$, and second in $2015(\mathrm{~N}=4992)$. Cross-sectional design was employed, and face-to-face survey was used in data collection. In the current study, data on the prevalence and extent of cannabis use, attitudes on cannabis use and policies regarding cannabis use, risk perception of cannabis use, as well as relevant characteristics of respondents were used. Data were analyzed using confidence intervals and latent class analysis (LCA). Cannabis use increased between the two study waves and the attitudes became more favorable. Three classes were obtained in the LCA in both waves: "non-users - cannabis conservative" (the biggest class), "rare to occasional users - cannabis liberal" (medium sized class) and "moderate to heavy users - very cannabis liberal" (the smallest class). The size of classes changed between the waves, with the latter two classes increasing in size in 2015. Results are discussed in the context of recent legal and societal events in Croatian society which might have driven the discovered changes in cannabis use and attitudes.
\end{abstract}


Key words: attitudes about cannabis, cannabis use, prevalence of cannabis use, general population, Croatia

\section{INTRODUCTION}

Cannabis is the most widely used illicit psychoactive substance in the world, with estimates showing that in $20173.8 \%$ (3.3\% - 4.4\% CI) of the global population aged 15-64 or 188 million people worldwide, had used cannabis at least once in the previous year (World Drug Report, 2019). According to a 2015 general population survey, cannabis was also the most widely used illicit drug in Croatia (Glavak Tkalić, Miletić, \& Maričić, 2016), 19.4\% of adults aged 15 to 64 years used cannabis at least once in their lives, and $7.9 \%$ of them and 16\% of young adults (aged 15 to 34 ) used cannabis during the last year. Although some people seem to use cannabis without adverse consequences (Fergusson, Boden \& Horwood, 2015), widespread cannabis use poses a burden on public health (Volkow et al., 2016). Studies suggest that approximately $9 \%$ of all users, and $15 \%$ of adolescent cannabis users develop dependence (Lopez-Quintero et al., 2011; Volkow et al., 2016). Furthermore, cannabis use is associated with adverse consequences, e.g. it increases the risk of car accidents due to impairments in psychomotor functioning and perception (Schulze et al., 2012) and intensive cannabis use during adolescence can lead to cognitive impairments and amotivational syndrome (Lac \& Luk, 2018; Lawn et al., 2016).

\section{Changes in cannabis use and attitudes}

Generally, attitudes and perceived risk towards a substance have a strong influence on the use of that substance (Cleveland, Feinberg, Bontempo, \& Greenberg, 2008). There are several theoretical frameworks addressing the relationship between attitudes and behavior, such as Outcome Expectancy Theory (Bandura, 1977) which proposes that the anticipated outcomes are influencing the likelihood of engaging in a certain behavior, such as substance use (e.g. Jones, Corbin, \& Fromme, 2001; McMillan \& Conner, 2003). Since beliefs and attitudes towards use of cannabis may contribute to the explanation of the prevalence of its use, it is important to continually monitor and investigate patterns of use and attitudes about cannabis, especially in the context of societal and legal changes (Miech et al., 2015). Most comprehensive data come from the epidemiological studies carried out in the US and Europe (NIDA, EMCDDA).

US studies show that attitudes became more favorable, with perceived risks of cannabis use decreasing in both adults and adolescents (Carliner, Brown, Sarvet, \& Hasin, 2017). In recent years, prevalence of cannabis use in the population of US adults has been steadily increasing from about 4\% in 1991 to about $13 \%$ in 2014 (Carliner et al., 2017). Similar trends can be observed in France, Germany, Finland, 
Denmark, Sweden and Ireland, where the prevalence of cannabis use increased among 15 to 34-year-olds between 2000 and 2015 (EMCDDA, 2017). Attitudes have also changed, and support for cannabis bans decreased among EU youth aged from 15 to 24 (Palladino, Hone \& Filippidis, 2018). Compared to 2008, the support for cannabis bans was, on average, 10 percentage points lower in 2011 and 18 percentage points lower in 2014, falling to 54\%, while support for cocaine and ecstasy bans were 2\% points lower in 2011 and 3\% points lower in 2014, remaining at values higher than $90 \%$. Moreover, a general trend emerged in Europe of associating cannabis with ecology, non-conformism, alternative culture and left-wing attitudes (EMCDDA, 2008).

Specific and detailed European country-level analyses done on representative population samples are, however, largely missing both in domains of cannabis use and cannabis attitudes. It has become especially important to analyze this data in recent years, when different factors which could contribute to more permissive cannabis attitudes and more widespread cannabis use came into play. Specifically, this study aims to give answers to the following questions: 1. Did cannabis use and attitudes change in the Croatian population between the two study waves (2011 and 2015)? 2. Which groups exist in the general population regarding cannabis use and attitudes and did they change between the two study waves?

\section{METHOD}

\section{Participants}

The research was conducted among the representative sample of residents of the Republic of Croatia aged between 15 and 64 years, in two consecutive general population surveys, in $2011(\mathrm{~N}=4756)$ and $2015(\mathrm{~N}=4992)^{1}$. The 2011 sample consisted of $43.9 \%$ male respondents and $56.1 \%$ female respondents and the 2015 sample consisted of $45.7 \%$ male respondents and $54.3 \%$ female respondents ${ }^{2}$. The studies in each wave were based on a single cross-sectional design, and face-to-face survey interviews were used in data collection in the respondents' households. The response rate was $53.1 \%$ in 2011 and $56.2 \%$ in 2015. The research obtained ethical approval from the Ivo Pilar Institute Ethics Committee.

1 Detailed methodology of the studies are presented in the research reports (Glavak Tkalić et al., 2012; Glavak Tkalić et al., 2016)

2 These are unweighted estimates. The data was afterwards weighted to represent the distribution of birth cohort and gender in the general population of Croatia. 


\section{Instruments}

Prevalence and patterns of drug use. In the current study, self-reported data on two categorical variables regarding the use of cannabis were chosen from the Croatian translation of the comprehensive European Model Questionnaire (EMQ), standardly used in national surveys on substance use among the general population: last year prevalence of cannabis use and regular use of cannabis at some point in life (Glavak Tkalić et al., 2016). Additional categorical variables regarding the selfreported use of various types of drugs were selected: "lifetime use of ecstasy", "lifetime use of amphetamines", "lifetime use of cocaine" and "lifetime use of LSD".

Attitudes and opinions regarding cannabis use and cannabis policies were represented by four variables. All were ordinal/continuous variables, which were converted into categorical variables, by using their response categories.

1) Attitudes about cannabis policies (cannabis legalization) were measured using the following question: "People should be permitted to take marijuana or hashish." (possible answers: fully agree, largely agree, neither agree nor disagree, largely disagree, fully disagree).

2) Attitudes regarding occasional use of cannabis were measured using the following question "Would you disapprove when people smoke marijuana or hashish occasionally?" (possible answers: do not disapprove, disapprove, strongly disapprove, I don't know).

3) Perceptions of cannabis use risks were represented by using the following question: "Do you consider it to be a risk if people smoke marijuana or hashish regularly?" (possible answers: no risk, slight risk, moderate risk, great risk).

4) Perceptions of cannabis use availability were measured using the following question: "How difficult or easy do you think it would be for you personally to obtain marijuana or hashish within 24 hours if you wanted some?" (possible answers: very easy, fairly easy, neither easy nor difficult, fairly difficult, very difficult).

Self-assessment of drug problem was assessed using a single question: "Do you think that you personally have a problem with drug use?" (possible answers: yes, no, I don't take drugs, and I don't know).

General Information on Participants Questionnaire. For the purpose of this research, a questionnaire was constructed in order to obtain personal information about participants' gender and age, and socio-economic status.

\section{RESULTS}

Confidence intervals were firstly inspected for overlap (Table 1) in order to assess the changes in cannabis use (last year prevalence of cannabis use and regular cannabis use at some point in life) and attitudes about cannabis policies and 
cannabis use between the two study waves (2011 and 2015) on a univariate level (Cumming \& Finch, 2005). ${ }^{3}$

Table 1. Confidence intervals for marijuana use and attitudes in 2011 and 2015 study waves

\begin{tabular}{|c|c|c|c|c|}
\hline \multirow[b]{3}{*}{ Outcome } & \multicolumn{4}{|c|}{ Year } \\
\hline & \multicolumn{2}{|c|}{2011} & \multicolumn{2}{|c|}{2015} \\
\hline & Estimate & $95 \% \mathrm{CI}$ & Estimate & $95 \% \mathrm{CI}$ \\
\hline Last year prevalence of cannabis use & 5.0 & $4.4-5.6$ & 7.9 & $7.1-8.7$ \\
\hline $\begin{array}{l}\text { Regular cannabis use at some point in } \\
\text { life }\end{array}$ & 2.9 & $2.4-3.4$ & 4.7 & $4.1-5.3$ \\
\hline \multicolumn{5}{|l|}{ Cannabis availability } \\
\hline Very easy/fairly easy to obtain & 32.8 & $31.4-34.2$ & 32.5 & $31.2-33.8$ \\
\hline Neither easy nor difficult to obtain & 15.6 & $14.5-16.7$ & 13.7 & $12.7-14.7$ \\
\hline Fairly difficult/very difficult to obtain & 51.6 & $50.1-53.1$ & 53.9 & $52.4-55.3$ \\
\hline \multicolumn{5}{|l|}{ Cannabis legalization } \\
\hline I don't agree at all / mostly don't agree & 66.9 & $65.5-68.3$ & 51.9 & $50.5-53.3$ \\
\hline I neither agree nor not agree & 14.9 & $13.8-16.0$ & 20.4 & $19.3-21.6$ \\
\hline I mostly agree / completely agree & 18.3 & $17.1-19.4$ & 27.7 & $26.4-29.0$ \\
\hline \multicolumn{5}{|l|}{ Occasional use of cannabis } \\
\hline I do not disapprove & 21.3 & $20.1-22.6$ & 28.1 & $26.8-29.4$ \\
\hline I disapprove & 26.8 & $25.5-28.1$ & 27.5 & $26.2-28.7$ \\
\hline I strongly disapprove & 43.8 & $42.3-45.3$ & 34.6 & $33.3-36.0$ \\
\hline I don't know & 8.1 & $7.3-9.0$ & 9.9 & $9.1-10.8$ \\
\hline \multicolumn{5}{|c|}{ Perceptions of risk related to regular use of cannabis } \\
\hline No risk & 1.8 & $1.4-2.2$ & 5.0 & $4.4-5.7$ \\
\hline Slight risk & 7.2 & $6.4-8.0$ & 12.2 & $11.3-13.2$ \\
\hline Moderate risk & 19.1 & $17.9-20.3$ & 24.4 & $23.3-25.7$ \\
\hline Great risk & 72.0 & $70.6-73.3$ & 58.3 & $56.9-59.7$ \\
\hline
\end{tabular}

Note: Values are shown in percentages. Bolded estimates for year 2015 indicate a statistically significant difference between the two waves.

$395 \%$ confidence intervals are considered a very conservative method for comparison, which corresponds to a $p$ value of roughly .005 , according to some simulations (Payton, Greenstone, \& Schenker, 2003). This was needed since multiple comparisons were made, and hence no additional corrections were applied. All parameters were calculated by using population weights in order to reflect the population values more accurately. 
Significant changes can be observed in cannabis use and attitudes, with higher use and more liberal attitudes in 2015 (Table 1). Last year prevalence of cannabis use rose from 5\% in 2011 to $7.9 \%$ in 2015 and the percentage of people who used cannabis regularly at some point in life also increased, from $2.9 \%$ in 2011 to $4.9 \%$ in 2015. Significantly more people endorsed cannabis legalization (an increase from $18.3 \%$ in 2011 to $27.7 \%$ in 2015) and didn't disapprove of occasional use of cannabis (an increase from $21.3 \%$ in 2011 to $28.1 \%$ in 2015). Perceptions of availability of cannabis however, didn't change between the waves.

As a further step, latent class analysis (LCA) was used to examine groups in the general population with regard to cannabis use and attitudes in 2011 and 2015 study waves and possible changes between them. Same variables were used in LCA as in confidence interval analysis, except "Perceptions of risk related to regular use of cannabis", which was not used. This variable is conceptually similar to the variable "attitudes about occasional use of cannabis" and it was deemed it would not add much to the model, while potentially also creating a lot of residual variation (Magidson \& Vermunt, 2004). To determine the optimal number of latent classes, models specifying different numbers of latent classes were run. Different models were compared by using various recommended indicators of fit (Nylund, Asparouhov, \& Muthén, 2007), including BIC, AIC, LMR-LRT, and entropy. To test the assumption of local independence, bivariate residuals were inspected (Magidson \& Vermunt, 2004). Maximum likelihood was used as the model estimation method and a sufficient number of random starts were used to avoid the local maxima.

Based on the lowest BIC and AIC, highest entropy and LMR-LRT indicator showing the best comparative fit $(p<.001)$, all while taking parsimony and theoretical and practical meaning of the classes into account (Collins \& Lanza, 2009); model with three classes was chosen in both waves over the models with one, two, four and five classes. However, inspection of bivariate residuals revealed that several of them were significant (i.e. larger than 1.96), meaning that the assumption of local independence should be relaxed (Oberski, 2016). Local dependencies between pairs of categorical variables with significant residuals were considered for freeing (Oberski, 2016), and the best and the final model was the one in which the dependency between the two attitude variables was freed. The final model for the 2011 wave had the $\mathrm{BIC}=33337.78, \mathrm{AIC}=33079.77$ and entropy of .898 . Final model for the 2015 wave had the $\mathrm{BIC}=38577.12$, AIC $=38317.08$ and entropy of .882 . These high values of entropy indicated a clear delineation between classes (Celeux \& Soromenho, 1996), with a high probability of individuals being correctly classified.

As already mentioned, best-fitting models for both waves consisted of three classes. What follows is a short description of each of them (see Table 2). The biggest class in both waves, Class 1, encompassed $79.0 \%$ of participants in the 2011 wave and $73.0 \%$ of participants in the 2015 wave. This class could be labeled as "nonusers - cannabis conservative" class, as they had very low probabilities for cannabis use in the last year and regularly at some point in life, and high probabilities for re- 
Table 2. Conditional probabilities for different outcomes as a function of being a member of a specific latent class for 2011 and 2015 study waves

\begin{tabular}{|c|c|c|c|c|c|c|}
\hline \multirow[b]{2}{*}{ Conditional probabilities } & \multicolumn{3}{|c|}{2011} & \multicolumn{3}{|c|}{2015} \\
\hline & $\begin{array}{c}\text { Class } 1 \\
\mathrm{~N}=3693 \\
79.0 \%\end{array}$ & $\begin{array}{c}\text { Class } 2 \\
\mathrm{~N}=848 \\
18.1 \%\end{array}$ & $\begin{array}{c}\text { Class } 3 \\
\mathrm{~N}=133 \\
2.9 \%\end{array}$ & $\begin{array}{c}\text { Class } 1 \\
\mathrm{~N}=3590 \\
73.0 \%\end{array}$ & $\begin{array}{c}\text { Class } 2 \\
\mathrm{~N}=1095 \\
22.3 \%\end{array}$ & $\begin{array}{c}\text { Class } 3 \\
\mathrm{~N}=233 \\
4.7 \%\end{array}$ \\
\hline \multicolumn{7}{|c|}{ Last year prevalence of cannabis use } \\
\hline Yes & .075 & .336 & .760 & .126 & .398 & .759 \\
\hline No & .925 & .664 & .240 & .874 & .602 & .241 \\
\hline \multicolumn{7}{|c|}{ Regular cannabis use at some point in life } \\
\hline Yes & .045 & .132 & .593 & .026 & .140 & .703 \\
\hline No & .955 & .868 & .407 & .974 & .860 & .297 \\
\hline \multicolumn{7}{|l|}{ Availability of cannabis } \\
\hline $\begin{array}{l}\text { Very easy/fairly easy to } \\
\text { obtain }\end{array}$ & .225 & .653 & .868 & .194 & .636 & .908 \\
\hline $\begin{array}{l}\text { Neither easy nor difficult to } \\
\text { obtain }\end{array}$ & .147 & .182 & .059 & .127 & .176 & .079 \\
\hline $\begin{array}{l}\text { Fairly difficult/very difficult } \\
\text { to obtain }\end{array}$ & .628 & .166 & .074 & .679 & .188 & .013 \\
\hline \multicolumn{7}{|l|}{ Cannabis legalization } \\
\hline $\begin{array}{l}\text { I don't agree at all / mostly } \\
\text { don't agree }\end{array}$ & .823 & .123 & .087 & .684 & .064 & .034 \\
\hline Neither agree nor not & .124 & .230 & .183 & .223 & .170 & .103 \\
\hline $\begin{array}{l}\text { I mostly agree / completely } \\
\text { agree }\end{array}$ & .052 & .647 & .731 & .093 & .766 & .864 \\
\hline \multicolumn{7}{|l|}{ Occasional use of cannabis } \\
\hline I do not disapprove & .039 & .840 & .901 & .055 & .892 & .955 \\
\hline I disapprove & .300 & .145 & .090 & .343 & .098 & .041 \\
\hline I strongly disapprove & .563 & .014 & .009 & .467 & .009 & .004 \\
\hline I don't know & .098 & .001 & .001 & .135 & .001 & .000 \\
\hline \multicolumn{7}{|l|}{ Lifetime use of ecstasy } \\
\hline Yes & .004 & .013 & .693 & .002 & .014 & .547 \\
\hline No & .996 & .987 & .307 & .998 & .986 & .453 \\
\hline \multicolumn{7}{|l|}{ Lifetime use of amphetamines } \\
\hline Yes & .004 & .008 & .806 & .002 & .010 & .657 \\
\hline No & .996 & .992 & .194 & .998 & .990 & .343 \\
\hline \multicolumn{7}{|l|}{ Lifetime use of cocaine } \\
\hline Yes & .004 & .017 & .604 & .002 & .013 & .473 \\
\hline No & .997 & .983 & .396 & .998 & .987 & .527 \\
\hline
\end{tabular}


Table 2. (Continued)

\begin{tabular}{|c|c|c|c|c|c|c|}
\hline \multirow[b]{2}{*}{ Conditional probabilities } & \multicolumn{3}{|c|}{2011} & \multicolumn{3}{|c|}{2015} \\
\hline & $\begin{array}{c}\text { Class 1 } \\
\mathrm{N}=3693 \\
79.0 \%\end{array}$ & $\begin{array}{c}\text { Class } 2 \\
\mathrm{~N}=848 \\
18.1 \%\end{array}$ & $\begin{array}{c}\text { Class } 3 \\
\mathrm{~N}=133 \\
2.9 \%\end{array}$ & $\begin{array}{c}\text { Class } 1 \\
\mathrm{~N}=3590 \\
73.0 \%\end{array}$ & $\begin{array}{c}\text { Class } 2 \\
\mathrm{~N}=1095 \\
22.3 \%\end{array}$ & $\begin{array}{c}\text { Class } 3 \\
\mathrm{~N}=233 \\
4.7 \%\end{array}$ \\
\hline \multicolumn{7}{|l|}{ Lifetime use of LSD } \\
\hline Yes & .001 & .012 & .406 & .001 & .003 & .332 \\
\hline No & .999 & .988 & .594 & .999 & .997 & .668 \\
\hline \multicolumn{7}{|c|}{ Self-assessment of drug problem } \\
\hline I don't take drugs & .937 & .784 & .253 & .906 & .760 & .211 \\
\hline Yes & .001 & .001 & .070 & .003 & .004 & .103 \\
\hline No & .062 & .215 & .677 & .092 & .236 & .686 \\
\hline
\end{tabular}

strictive attitudes about cannabis; namely for thinking it shouldn't be legal, strongly disapproving occasional cannabis use, and considering cannabis being fairly difficult or very difficult to obtain. The probability of using other drugs at least once in a lifetime or having problems with drugs was close to zero in both waves for this class.

The second biggest class in both waves, Class 2, encompassed $18.1 \%$ of participants in the 2011 wave and $22.3 \%$ of participants in the 2015 wave. This class could be labeled as "rare to occasional users - cannabis liberal". This class had a moderate probability of using cannabis during the last year, but a low probability of using cannabis regularly at some point in life. It had high probabilities for endorsing cannabis legalization, not disapproving of occasional cannabis use, and relatively high probabilities for considering cannabis easy or very easy to obtain. Probabilities for using other drugs at least once in lifetime or having problems with drugs were close to zero.

The smallest class in both waves, Class 3, encompassed $2.9 \%$ of participants in the 2011 wave and $4.7 \%$ of participants in the 2015 wave. This class could be labeled as "moderate to heavy users - very cannabis liberal". This class had a high probability of using cannabis in the last year, and relatively high probability of being a regular cannabis user at some point in life. They had the highest probabilities for liberal attitudes about cannabis, namely for thinking it should be legal, not disapproving occasional cannabis use, and considering cannabis easy or very easy to obtain. They also had moderate to high probabilities of using other drugs at least once in their lifetime. They had a high probability of giving the answer "No" to the question about drug problems, as opposed to "I don't take drugs", suggesting they use drugs but do not perceive having a problem because of it. There was also a small probability of giving the answer "yes" to this question. 
As can be observed, Class 1 (non-users - cannabis conservative) decreased in its relative size in 2015, as opposed to 2011. Likewise, Class 2 (rare to occasional users - cannabis liberal) has grown in 2015 , as well as the moderate to heavy using Class 3.

Some differences can also be observed in conditional probabilities between the two waves, moving in the direction of more use and more liberal attitudes within the classes in 2015 than in 2011: a higher probability can be observed for Class 3 using cannabis regularly at some point in their lives in 2015 than in 2011, and lower probability can be observed for Class 1 for not agreeing with cannabis legalization in 2015 than in 2011.

\section{DISCUSSION}

The results of this study point to the significant change of last year prevalence in cannabis use between the 2011 and 2015 study waves, with higher last year prevalence in 2015. Concurrently, the significant changes between the two study waves were observed in attitudes and opinions regarding cannabis use and cannabis related policies - namely, more people agreed that people should be allowed to use cannabis, less people were against occasional use of cannabis and less people associated regular use of cannabis with great risk, all pointing out to more permissive attitudes in 2015 than in 2011.

Results of the LCA provided a deeper insight by uncovering three latent classes which are present in both waves: the biggest "non-users - cannabis conservative" class, middle-sized "rare to occasional users - cannabis liberal" class and the smallest "moderate to heavy users - very cannabis liberal" class. The two smaller, "cannabis using" classes grew in size in the 2015 wave as opposed to the 2011 wave, the biggest class decreased in its size and there are some differences in conditional probabilities - pointing to a shift towards more cannabis use and more permissive attitudes in the general population.

Two factors can be taken into consideration that could have led to this outcome. First factor is the decriminalization of cannabis use in Croatia in 2013 (Official Gazette, 125/11). Decriminalization refers to the use of cannabis for recreational purposes remaining illegal, but criminal sanctions being removed and, in some cases, replaced by other civil penalties such as fines (Waddell \& Wilson, 2017). Some studies have found an increase in cannabis use after its decriminalization (e.g. Williams, \& Bretteville-Jensen, 2014; Miech et al., 2015), however such results are to be interpreted with caution because of (obvious) lack of experimental evidence, which brings difficulties in inferring causality in these cases (Laqueur, 2015; Leung, Chiu, Chan, Stjepanović, \& Hall, 2019).

Second factor that can be taken into consideration is an increased amount of attention in the Croatian media that has been given to medical cannabis and its 
benefits (e.g. Index.hr, 2015). These articles appeared in the light of public debate due to anticipated legal changes regarding medical marijuana, which were eventually introduced in October 2015, and medicines which contain tetrahydrocannabinol (THC), dronabinol and nabilone were allowed as a medically proscribed means of providing symptom relief for multiple sclerosis, carcinomas, epilepsy and AIDS (Official Gazette, 107/2015). A recent experimental study (Sznitman \& Lewis, 2018) has shown that merely showing testimonials of patients who use medical cannabis to participants can make their attitudes and beliefs more permissive and increase their intentions towards using both medical and recreational cannabis. Evidence also comes from a recently conducted Gallup poll (2019), where $86 \%$ of Americans who support cannabis legalization stated that perceived benefits to those who use cannabis for medical reasons were a very important reason for their cannabis legalization support. Felson, Adamczyk and Thomas (2018) further reinforce the medical reporting argument, stating that the influential and reputative New York Times stopped coupling cannabis with other drugs such as cocaine or heroin during last 15-20 years and started writing about it in the context of palliative care, which partially coincided with the liberalization of attitudes towards cannabis in the US. Some articles in the Croatian media also mentioned possible economic benefits of cannabis legalization (e.g. Tportal, 2014), which is an argument that could be attractive to people coming from all sides of the political spectrum, and not just the left-winged who are found to have more favorable attitudes about cannabis (Cruz, Queirolo, \& Boidi, 2016).

\section{Limitations}

This study does not employ a longitudinal design, and this limits possible analyses and conclusions that could be drawn from the data (e.g. variables moderating the change in cannabis use and attitudes might have been examined, or latent transition analysis might have been used). Also, although the employed methodological procedure was designed while adhering to strict standards and best practices (Glavak Tkalić et al., 2012; Glavak Tkalić, et al., 2016) it is possible that social desirability influenced the participants' responses. An indicator of cannabis use disorder was measured only in the 2015 wave, and therefore couldn't be used in this study. It would have been interesting to see if this too has changed, since US found that, between 2002 and 2014, increases occurred in general and daily cannabis use, but not in rates of cannabis use disorder (Compton, Han, Jones, Blanco \& Hughes, 2016).

\section{Future studies}

Classes 2 and 3 obtained with latent class analysis are interesting for further study. Class 3 had high probabilities of both cannabis use and liberal attitudes, 
while Class 2 had an even more interesting profile: for this class there were high probabilities for endorsing cannabis legalization and not disapproving its use, and for perceiving cannabis as easy or very easy to obtain, but they still did not have a high probability of using cannabis in the last year and had low probability of using it regularly at some point. It would be interesting to see which sociodemographic characteristics, personality traits and coping mechanisms are related to membership in Class 3 and in Class 2, because members of Class 2 seem to have cannabis and drug usage patterns which would indicate lower risk of harm, while for members of Class 3, the risk is noticeably higher. With one more wave of the study, it would be possible to observe whether cannabis use will continue to increase and whether cannabis attitudes would become yet more favorable, which would allow us to draw conclusions about trends.

\section{REFERENCES}

Bandura, A. (1977). Social learning theory. Englewood Cliffs, NJ: Prentice Hall.

Carliner, H., Brown, Q. L., Sarvet, A. L., \& Hasin, D. S. (2017). Cannabis use, attitudes, and legal status in the US: a review. Preventive medicine, 104, 13-23. doi:10.1016/j. ypmed.2017.07.008

Celeux, G., \& Soromenho, G. (1996). An entropy criterion for assessing the number of clusters in a mixture model. Journal of Classification, 13(2), 195-212. doi:10.1007/ BF01246098

Cleveland, M. J., Feinberg, M. E., Bontempo, D. E., Greenberg, M. T. (2008). The role of risk and protective factors in substance use across adolescence. The Journal of Adolescent Health, 43, 157-164. doi:10.1016/j.jadohealth.2008.01.015

Collins, L. M., \& Lanza, S. T. (2009). Latent class and latent transition analysis: With applications in the social, behavioral, and health sciences. John Wiley \& Sons. doi:10.1002/9780470567333

Compton, W. M., Han, B., Jones, C. M., Blanco, C., \& Hughes, A. (2016). Marijuana use and use disorders in adults in the USA, 2002-14: analysis of annual cross-sectional surveys. The Lancet Psychiatry, 3(10), 954-964. doi:10.1016/S2215-0366(16)30208-5

Cruz, J. M., Queirolo, R., \& Boidi, M. F. (2016). Determinants of public support for marijuana legalization in Uruguay, the United States, and El Salvador. Journal of Drug Issues, 46(4), 308-325. doi:10.1177/0022042616649005

Cumming, G., \& Finch, S. (2005). Inference by eye: confidence intervals and how to read pictures of data. American Psychologist, 60(2), 170. doi:10.1037/0003-066X.60.2.170

EMCDDA (n.d.). [Publications]. Retrieved from http://www.emcdda.europa.eu/publications_en

EMCDDA (2008). A cannabis reader: global issues and local experiences (Vol. 2, No. 8). Lisbon: European Monitoring Centre for Drugs and Drug Addiction.

EMCDDA (2017). European Drug Report: Trends and Use. Lisbon: European Monitoring Centre for Drugs and Addiction. 
Felson, J., Adamczyk, A., \& Thomas, C. (2018). How and why have attitudes about cannabis legalization changed so much? Social science research, 78, 12-27. doi: https://doi. org/10.1016/j.ssresearch.2018.12.011

Fergusson, D. M., Boden, J. M., \& Horwood, L. J. (2015). Psychosocial sequelae of cannabis use and implications for policy: findings from the Christchurch Health and Development Study. Social psychiatry and psychiatric epidemiology, 50(9), 1317-1326. doi: 10.1007/s00127-015-1070-x

Gallup (2019). In U.S., Medical Aid Top Reason Why Legal Marijuana Favored. Retrieved from https://news.gallup.com/poll/258149/medical-aid-top-reason-why-legal-marijuana-favored.aspx

Glavak Tkalić, R., Miletić, G. M., Maričić, J., \& Wertag, A. (2012). Substance abuse among the general population in the Republic of Croatia: Research report. Zagreb: Institute of Social Sciences Ivo Pilar and Government of the Republic of Croatia - Office for Combating Drug Abuse.

Glavak Tkalić, R., Miletić, G. M., \& Maričić, J. (2016). Uporaba sredstava ovisnosti u hrvatskom društvu: Istraživanje na općoj populaciji [Substance Use in the Croatian Society: Research among the General Population]. Zagreb: Institute of Social Sciences Ivo Pilar and Government of the Republic of Croatia - Office for Combating Drug Abuse.

Index.hr (2015). Dr. Brborović otkriva sve o legalizaciji marihuane u Hrvatskoj: Nema dileme, ona je i droga i lijek [Dr. Brborović reveals everything about marijuana legalization in Croatia: There is no dilemma, marijuana is both a drug and a cure]. Retrieved from: https://www.index.hr/vijesti/clanak/Dr-Brborovic-otkriva-sve-o-legalizaciji-marihuane-u-Hrvatskoj-Nema-dileme-ona-je-i-droga-i-lijek/812574.aspx

Jones, B. T., Corbin, W., \& Fromme, K. (2001). A review of expectancy theory and alcohol consumption. Addiction, 96(1), 57-72. doi:10.1046/j.1360-0443.2001.961575.x

Lac, A., \& Luk, J. W. (2018). Testing the amotivational syndrome: Marijuana use longitudinally predicts lower self-efficacy even after controlling for demographics, personality, and alcohol and cigarette use. Prevention Science, 19(2), 117-126. doi:10.1007/s11121017-0811-3

Laqueur, H. (2015). Uses and abuses of drug decriminalization in Portugal. Law \& Social Inquiry, 40(3), 746-781. doi:10.1111/1si.12104

Lawn, W., Freeman, T. P., Pope, R. A., Joye, A., Harvey, L., Hindocha, C., ... \& Das, R. K. (2016). Acute and chronic effects of cannabinoids on effort-related decision-making and reward learning: an evaluation of the cannabis amotivational' hypotheses. Psychopharmacology, 233(19-20), 3537-3552. doi:10.1007/s00213-016-4383-x

Leung, J., Chiu, V., Chan, G. C., Stjepanović, D., \& Hall, W. D. (2019). What have been the public health impacts of cannabis legalisation in the USA? A review of evidence on adverse and beneficial effects. Current Addiction Reports, 1-11. doi:10.1007/s40429019-00291-x

Lopez-Quintero, C., de los Cobos, J. P., Hasin, D. S., Okuda, M., Wang, S., Grant, B. F., \& Blanco, C. (2011). Probability and predictors of transition from first use to dependence on nicotine, alcohol, cannabis, and cocaine: Results of the National Epidemiologic Survey on Alcohol and Related Conditions (NESARC). Drug and Alcohol Dependence, 115(1-2), 120-130. doi:10.1016/j.drugalcdep.2010.11.004 
Magidson, J., \& Vermunt, J. K. (2004). Latent class models. In Kaplan, D. (Ed), The Sage handbook of quantitative methodology for the social sciences, 175-198. Newbury Park: SAGE publishing. doi:10.4135/9781412986311.n10

McMillan, B., \& Conner, M. (2003). Applying an extended version of the theory of planned behavior to illicit drug use among students. Journal of Applied Social Psychology, 33, 1662-1683. doi:10.1111/j.1559-1816.2003.tb01968.x

Miech, R. A., Johnston, L., O’Malley, P. M., Bachman, J. G., Schulenberg, J., \& Patrick, M. E. (2015). Trends in use of marijuana and attitudes toward marijuana among youth before and after decriminalization: The case of California 2007-2013. International Journal of Drug Policy, 26(4), 336-344. doi:10.1016/j.drugpo.2015.01.009

National Institute on Drug Abuse [NIDA]. (n.d.). [Publications]. Retrieved from https:// www.drugabuse.gov/publications

Nylund, K. L., Asparouhov, T., \& Muthén, B. O. (2007). Deciding on the number of classes in latent class analysis and growth mixture modeling: A Monte Carlo simulation study. Structural equation modeling: A multidisciplinary Journal, 14(4), 535-569. doi:10.1080/10705510701575396

Oberski, D. L. (2016). Beyond the number of classes: separating substantive from nonsubstantive dependence in latent class analysis. Advances in Data Analysis and Classification, 10(2), 171-182. doi:10.1007/s11634-015-0211-0

Official Gazette (2013). Kazneni zakon [Penal Code]. Zagreb: Ministarstvo pravosuđa Republike Hrvatske [Ministry of Justice of the Republic of Croatia].

Official Gazette (2015). Pravilnik o izmjenama i dopunama pravilnika o mjerilima za razvrstavanje lijekova te o propisivanju i izdavanju lijekova na recept.[A rulebook on changes and addendums to the rulebook on criteria for classification of medicines and on proscribing and dispensing prescription medicines]. Zagreb: Ministarstvo zdravstva [Ministry of Health].

Palladino, R., Hone, T., \& Filippidis, F. T. (2018). Changes in support for bans of illicit drugs, tobacco, and alcohol among adolescents and young adults in Europe, 2008-2014. International journal of public health, 63(1), 23-31. doi:10.1007/s00038-017-1025-y

Payton, M. E., Greenstone, M. H., \& Schenker, N. (2003). Overlapping confidence intervals or standard error intervals: what do they mean in terms of statistical significance? Journal of Insect Science, 3(1). doi:10.1673/031.003.3401

Schulze, H., Schumacher, M., Urmeew, R., Alvarez, J., Bernhoft, I. M., de Gier, H. D. G., ... \& Zlender, B. (2012). Driving under the influence of drugs, alcohol and medicines in Europe - findings from the DRUID project. Retrieved from http://www.emcdda.europa. eu/publications/thematic-papers/druid_en

Sznitman, S. R., \& Lewis, N. (2018). Examining effects of medical cannabis narratives on beliefs, attitudes, and intentions related to recreational cannabis: A web-based randomized experiment. Drug and alcohol dependence, 185, 219-225. doi:10.1016/j.drugalcdep.2017.11.028

Tportal (2014). Zašto je legalizacija trave dobra za zdravlje i ekonomiju? [Why is the legalization of weed good for health and the economy?] Retrieved from https://www.tportal. hr/vijesti/clanak/zasto-je-legalizacija-trave-dobra-za-zdravlje-i-ekonomiju-20140117

United Nations Office on Drugs, \& Crime (2019). World drug report 2019. Retrieved from https://wdr.unodc.org/wdr2019/ 
Volkow, N. D., Swanson, J. M., Evins, A. E., DeLisi, L. E., Meier, M. H., Gonzalez, R., ... \& Baler, R. (2016). Effects of cannabis use on human behavior, including cognition, motivation, and psychosis: a review. JAMA psychiatry, 73(3), 292-297. doi:10.1001/ jamapsychiatry.2015.3278

Waddell, K., \& Wilson, M. G. (2017). Rapid synthesis: Examining the impact of decriminalizing or legalizing Cannabis for recreational use. Hamilton, Canada: McMaster Health Forum.

Williams, J., \& Bretteville-Jensen, A. L. (2014). Does liberalizing cannabis laws increase cannabis use? Journal of Health Economics, 36, 20-32. doi:10.1016/j.jhealeco.2014.03.006

\title{
STAVOVI O KANABISU I KONZUMIRANJU KANABISA U DVA UZASTOPNA ISTRAŽIVANJA U OPĆOJ HRVATSKOJ POPULACIJI
}

\begin{abstract}
Sažetak
Kanabis je najčešće korištena ilegalna droga u Hrvatskoj. Iako se čini da neki ljudi kanabis konzumiraju bez značajnih štetnih posljedica, raširenost uporabe kanabisa još je uvijek značajan teret javnom zdravstvu. Ciljevi ovog istraživanja bili su utvrditi jesu li se prevalencija uporabe kanabisa i stavovi o uporabi kanabisa promijenili između dva vala istraživanja i koje grupe postoje u općoj populaciji Hrvatske s obzirom na uporabu kanabisa i stavove o uporabi kanabisa te je li došlo do promjena u njima između dva vala istraživanja. Istraživanje je provedeno na dva reprezentativna uzorka hrvatskih građana u dobi između 15 i 64 godine, prvo 2011. (N=4756), a drugo 2015. godine ( $\mathrm{N}=4992)$. Korišten je transverzalni nacrt, a podaci su prikupljani istraživanjem licem u lice. U ovom istraživanju korišteni su podaci o prevalenciji i razmjerima uporabe kanabisa, stavovima o uporabi kanabisa i politici vezanoj uz uporabu kanabisa, percepciji rizika vezanog uz uporabu kanabisa, te pojedine karakteristike sudionika. Podaci su analizirani korištenjem intervala pouzdanosti i analize latentnih klasa (LCA). Prevalencija uporabe kanabisa povećala se između dva istraživanja, a stavovi postali liberalniji. Korištenjem LCA utvrđene su tri klase u oba vala istraživanja: "nekonzumenti - kanabis konzervativni” (najveća klasa), "rijetki do povremeni konzumenti - kanabis liberalni" (klasa srednje veličine) i "umjereni do redoviti konzumenti - vrlo kanabis liberalni" (najmanja klasa). Veličina klasa promijenila se između dvaju istraživanja na način da su se zadnje dvije klase povećale u 2015. godini. Rezultati su predstavljeni u kontekstu nedavnih pravnih i društvenih promjena u hrvatskom društvu koje su mogle dovesti do utvrđenih promjena u prevalenciji uporabe kanabisa i stavovima o kanabisu.
\end{abstract}

Ključne riječi: stavovi o kanabisu, uporaba kanabisa, prevalencija uporabe kanabisa, opća populacija, Hrvatska

Primljeno: 11. 12. 2019. 